\title{
JUURNAL.RU
}

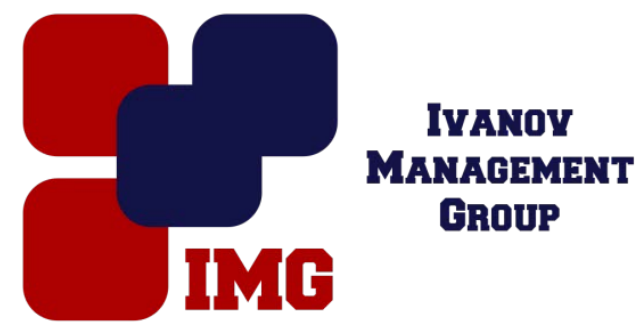

Гончарова А.В. Российская Академия Народного Хозяйства и Государственной службы при Президенте РФ Москва, Россия

doi: 10.18411/lj-28-02-2017-4-03

idsp 000001:lj-28-02-2017-4-03

\section{Функционирование эквивалентных глаголов и словосочетаний}

В современной лингвистике проблемы семантики приобрели особенно важное значение в связи с необходимостью обоснования закономерностей функционирования речевых единиц в процессе коммуникации. "Исследование языка, с точки зрения его коммуникативного предназначения и с точки зрения его семантического наполнения, неизбежно требует выхода за поверхностные формы языка в тот уровень, который определяет информативную ценность языковых единиц".

В свете этого положения несомненный интерес представляет проблема эквивалентности слов и словосочетаний, которые, обладая значительным сходством в предметно-логическом содержании» не являются полными синонимами, и выбор одного из них часто определяется интенцией говорящего.

Эквивалентные слова и словосочетания исследовались в Российской и зарубежной лингвистике с различных позиций. У.Чейф рассматривает такие пары как имеющие сходное, но не идентичное значение, поскольку, передавая мысль другими словами, мы воспроизводим лишь общее значение, основной смысл, а "любое изменение означающего - способа выражения - по крайней мере, коннотативно, модифицирует и означаемое. В.В.Лопатинская сопоставляет глаголы и одноименные им глагольно-именные и глагольно-адъективные словосочетания для установления их отношения к синонимии. М.Д.Степанова и Е.С.Кубрякова считают такие пары различными поверхностными реализациями общей глубинной структуры, когда производные слова включают в себя "скрытые" смысловые грамматические отношения. Л.Н.Бычко анализирует их как проявление способности языка выражать одно и то же содержание различными средствами.

Цель данной статьи - установить характер семантической эквивалентности однословных глаголов и соотносительных словосочетаний и выявить признаки сходства или различия при их функционировании в тексте. Вслед за И.В.Арнольд 
эквивалентность трактуется как "такое отношение между лингвистическими единицами, когда они обладают какими-либо общими свойствами, позволявшими им выполнять одинаковую функцию".

Объектом анализа служат отадъективные конверсивы и глаголы с суффиксом -en (to slow, to darken) и синонимичные им глагольно-адъективные словосочетания, обозначающие качественные изменения одушевленного и неодушевленного объекта - его цвета, формы, состояния, внешности, физической и интеллектуальной характеристики, например; to. get dark, to make slow, to be idle.

Исследуемые однословные глаголы и словосочетания проявляют значительное сходство в семантике. Обозначая качественные изменения объекта, они подразделяются на 3 типа: 1) каузирование признака (в результате воздействия субъекта объект приобретает новое качество или переходит в новое состояние, отличающееся от исходного), например: Her tears wetted my cheek (HS, p.131). The doctor tried to loosen Sean's hands from his jacket (WL, p.26). I got my place free and clear; 2) становление признака (появление нового качества или переход в новое состояние происходит в самом предмете без воздействия извне), например: The wind slacked a little at last (HS, p.181). Her tone softened a little (Tres., p.352); 3) выявление признака (утверждается наличие или отсутствие признака или состояния), например: The way other people do business is so dull (CMC, p.272); It's a handicap being nearly blind and deaf (TG, p.39).

Семантическая эквивалентность глаголов и словосочетаний находит выражение в наличии исследуемых словосочетаний в словарных дефинициях глаголов, например: to darken - to get dark, to slow -to make slow, to loosen - to get loose, to narrow - to become narrow. Характер передаваемых значений позволяет им вступать в антонимические отношения, что свидетельствует о высокой степени родства. Сравните: He sat for half an hour considering the rocket and the house lights and his eyes narrowed and grew wide (Br., p.224).

Однако количественное распределение глаголов и словосочетаний по указанным трем типам неодинаково: глаголы чаще обозначают каузирование и становление признака, словосочетания - выявление признака.

В составе исследуемых словосочетаний функционируют практически все имевшиеся глаголы-связки. Традиционно принято считать, что их лексическое значение в сильной степени утрачено. Однако, как отмечает В.В.Бурлакова, частичная или полная утрата лексического значения присуща лишь немногим связочным глаголам, большинство же связок сохраняют его почти в той же мере, что и при функционировании в качестве знаменательных'. Сравнение синонимичных глаголов и словосочетаний показывает, что последние способны более наглядно передавать действие как протекающий процесс, подчеркивая его динамику, переход от одной стадии протекания процесса к другой. Сравните:

The lamp began to turn dim (KF, p.397).

The smoky mist and yet smokier night dimmed the lights gloucester spread below (HS, p.140).

Важной характеристикой, объединяющей исследуемые глаголы и словосочетания, является предельность. Значение предельности в первую очередь 
принадлежит содержанию действия и качества и поэтому, как считает Г.Н.Воронцова, чаще всего наблюдается у глаголов и прилагательных, хотя характер предельности у этих лексико-грамматических классов различен.

Спецификой исследуемых глаголов и словосочетаний является то, что в них комбинируется своеобразие предельности, присущей прилагательным и глаголам: они обозначают различные качественные изменения, и потому пределом в их лексическом значении отчетливо выступает достижение той или иной степени качества, обозначенного мотивирующим прилагательным. Однословный глагол может обозначать как приобретение нового качества, так и изменение степени насыщения признаком, которым предмет уже обладал. Указание на это содержится в дефиниции глагола в виде сравнительной степени Прилагательного, например: to fine down - to make gradually finer; to narrow - to make narrow or narrower. Это указание является факультативным и, как правило, требует дополнительной конкретизации в тексте. Например:

The car engine idled (HS, p.194).

After a while he calmed down a little (HS, p.131).

Словосочетание в силу своей расчлененности способно более дифференцировано фиксировать изменение степени признака, сосредоточивая внимание на динамике процесса. Например; it got darker (RCh., p.178); Then he began to read in a low trembling voice that grew firmer as he progressed from line to line (F, p.107).

Это свойство словосочетаний может быть использовано для создания стилистического эффекта, когда необходимо описать процесс, подчеркивая его динамику, переход от одного этапа к другому, и отдалить во времени достижение предела. Значение процессности усиливается, с одной стороны, лексическим значением глагола-связки, обозначавшим становление признака, с другой повторением прилагательного в сравнительной степени. Например: The humming grew louder, louder, higher, higher, wilder, stranger, more exhilarating, trembling in him and leaning him forward (Br, p.223).

Исследуемые глаголы и словосочетания могут совпадать или различаться по субъектно-объектной направленности действия. Глагольные лексемы с семантической структурой, однородной по субъектно-объектной характеристике, составляют незначительную часть анализируемых однословных глаголов, Их семантической структуре присуще комбинирование субъектных и объектных ЛСФ, при этом преобладают объектные ЛСЗ. Словосочетание всегда однонаправлено, четко ориентировано только на субъект или объект значением глагола-связки. В ряде случаев словосочетание компенсирует отсутствие соответствующего ЛСВ у глагола.

Таким образом, проведенное исследование показало, что, обладая высокой степенью семантической эквивалентности, однословные глаголы и словосочетания, обозначающие качественные изменения, не являются абсолютно идентичными. Определенные различия, проявляющиеся при их функционировании, обусловлены различиями в их семантике и интенцией говорящего. 


\section{Список сокращений}

- ЛСВ - лексико-семантический вариант

- BS - Gilden K.B. Hurry Sundown. Signet Book, 2011

- WL - Smith W. When the Lion Feeds. London, 2010

- Tres. - Knebel F. Trespass. N.Y., 2013

- CMC - Hawley C. Cash McCall. London, Consul Book, 2012

- TG - Christis A. Third Girl. N.Y., 2011

- Br. - Bradbury R. Selected Stories. M., Raduga Publishers, 2014.

\section{Литература}

1. Принципы и методы семантических исследований. М.: Наука; 2007.

2. Чейф У.Л. Значение и структура языка. М., 2010.

3. Лопатинская 3.3. Опыт сопоставления глаголов и одноименных им глагольно-именных и глагольно-адъективных словосочетаний: Автореф. дис. ... канд. филол. наук. Львов, 2004.

4. Степанова М.Д. К вопросу о семантических корреляциях синтаксических и словообразовательных структур. - В кн.: Проблемы синтаксической семантики: Материалы научной конференции, М., Кубрякова Е.С. Семантика синтаксиса и некоторые проблемы словообразования. - Там же, 2011.

5. Бычко Л.Н. Перифрастика в современном английском языке. - В кн.: Сборник научных трудов МГЛУ. М., вып. 134, 2006.

6. Арнольд И.В. Эквивалентность как лингвистическое понятие. - ВЯ, № I, изд.4, 2010.

7. Бурлакова В.В. Синтаксические структуры современного английского языка. М.: Просвещение, 2014.

8. Воронцова Г.Н. Очерки по грамматике английского языка. М., изд.2, 2012.

9. Гончарова А.В. Перформативные глаголы как вербальные выразители иллокутивной силы высказывания. Тенденции развития науки и образования. Сборник научных трудов по материалам Международной научно-практической конференции 25 декабря 2015, изд. НИЦ, Л-Журнал, Самара, 2015. 